\title{
Evaluating the Potential for Rearing Walleye in Lined Ponds Filled with Well Water
}

\author{
Matthew J. Ward (Corresponding author) \\ South Dakota Department of Game, Fish and Parks, Blue Dog State Fish Hatchery \\ 44437 139A Street, Waubay, South Dakota, 57273, United States
}

Tel: 1-605-947-4657

Nathan A. Pool

South Dakota Department of Game, Fish and Parks, Blue Dog State Fish Hatchery 44437 139A Street, Waubay, South Dakota, 57273, United States

Tel: 1-605-947-4657

Chad R. Haabala

South Dakota Department of Game, Fish and Parks, Blue Dog State Fish Hatchery 44437 139A Street, Waubay, South Dakota, 57273, United States

Tel: 1-605-947-4657

Ryan A. Rasmus

South Dakota Department of Game, Fish and Parks, Blue Dog State Fish Hatchery 44437 139A Street, Waubay, South Dakota, 57273, United States

Tel: 1-605-947-4657

Received: February 25, 2021 Accepted: March 17, 2021 Published: March 19, 2021

doi:10.5296/ast.v9i2.18431 URL: https://doi.org/10.5296/ast.v9i2.18431 


\section{Abstract}

Walleye (Sander vitreus) fingerlings (30 to $35 \mathrm{~mm}$ ) are commonly reared in ponds filled with surface (i.e., lake) water, but the use of ground (i.e., well) water would provide increased biosecurity. We assessed the potential for using well water to rear walleye by comparing plankton and water quality over 30 days between organically fertilized lined ponds that were filled with either unfiltered lake or well water. All ponds were inoculated with plankton that originated from Blue Dog Lake, filled by May 15, 2020, and remained fishless. Zooplankton density and body size were consistently reduced in well ponds suggesting that fry survival and growth would be reduced. Initially, well ponds exhibited higher ammonia-nitrogen and alkalinity, but lower $\mathrm{pH}$ owing to the inherent chemistry of the well water. Later, reduced ammonia-nitrogen combined with increased dissolved oxygen and $\mathrm{pH}$ suggest that decomposition of the organic fertilizer occurred slower in well ponds. A phytoplankton bloom was successfully initiated but was difficult to maintain despite consistently lower zooplankton density in well ponds. While the use of well water would enhance biosecurity, these data suggest that walleye fingerling production would be reduced relative to lined ponds filled with productive, lake water. Increasing organic fertilizer, supplementing with liquid 28N:0P:0K, and/or filling ponds earlier (e.g., 30 days) may provide a more favorable environment for walleye culture in lined ponds filled with well water.

Keywords: Walleye, lined ponds, well water

\section{Introduction}

Surface waters have historically been used to fill ponds for rearing walleye (Sander vitreus) fingerlings at many locations (Summerfelt et al., 1996). Surface waters provide nutrients (Rogge et al., 2003) and plankton that can solely support walleye production (Harding \& Summerfelt, 1993) or in most cases, initiate a food web which is then enhanced by fertilization (Culver, 1996; Summerfelt et al., 2011). Organic fertilizers provide immediate nourishment for zooplankton (Barkoh \& Rabeni, 1990) and release nutrients during decomposition (Boyd \& Tucker, 2014). The decomposition process reduces dissolved oxygen (Qin \& Culver, 1992; Soderberg, 2012) and pH (Boyd \& Tucker, 2014). Moreover, the release of nutrients promotes algae needed to sustain large zooplankters that can overgraze phytoplankton (Qin \& Culver, 1995). Walleye initially consume zooplankton, which remain important in their diet for at least the first 21 days of pond culture (Summerfelt et al., 2011; Briland et al., 2015).

Well (i.e., ground) water typically has differing chemistry and is relatively sterile compared to surface waters (Boyd, 1990; Summerfelt et al., 2011). As such, well ponds require plankton inoculation (Summerfelt et al., 2011). Further, ponds filled with well water generally require a longer time to develop an adequate forage base for fish production. At northern latitudes, however, filling ponds earlier in the spring may coincide with low temperatures that are not necessarily conducive to food web development (Smith \& Moyle, 1945).

Aquatic invasive species, such as zebra mussels (Dreissena polymorpha), continue to infest new waters (Karatayev et al., 2015) and pose substantial risks to water supply systems 
(Chakraborti et al., 2016). Rearing walleye in ponds filled with well water would protect hatchery infrastructure from zebra mussels but may impact fingerling production. The objective of this study was to evaluate the potential for rearing walleye in lined ponds filled with well water. To do so, we compared zooplankton and water quality, as well as phytoplankton and chlorophyll-a between lined ponds that were filled with either unfiltered lake or well water in the absence of fish. The comparison began 3 days after all lake ponds were filled in accordance with the proven practice of a short timeline between pond filling and stocking (e.g., < 7 days) when surface water is used (Culver et al., 1993).

\section{Method}

\subsection{Study Site and Design}

This study occurred at Blue Dog State Fish Hatchery, Waubay, South Dakota, USA $\left(45^{\circ} 21^{\prime} 30.89^{\prime \prime} \mathrm{N}, 97^{\circ} 19^{\prime} 03.63^{\prime \prime} \mathrm{W}\right)$ in eight, 0.72-hectare lined ponds that were filled with unfiltered water from either Blue Dog Lake $(n=4$; hereafter lake ponds) or hatchery wells ( $\mathrm{n}=4$; hereafter well ponds). A description of water chemistry parameters for each water source is presented in Table 1 and the lake water used in this study is considered eutrophic (Stueven \& Bren, 1999). Well ponds began receiving water up to 10 days earlier than those that received lake water because of reduced availability of well water and a longer time required to fill ponds. As well ponds were filling, they received approximately 300 milliliters of zooplankton randomly collected with a net (80-micron mesh) from Blue Dog Lake. The zooplankton were transferred to the ponds in 11.4 liters of lake water, which also allowed for initial phytoplankton inoculation. We assumed that the relative plankton composition was similar to that in ponds filled with unfiltered lake water because all plankton originated from Blue Dog Lake during early May. The quantity of plankton that was initially pumped into ponds filled with lake water was unquantified but was most likely greater than that used to inoculate well ponds. All ponds were filled by May 15, 2020 and received 387 kilograms of alfalfa meal (Medicago sativa; $17 \%$ protein, Green Meadows Forage, Gayville, South Dakota, USA) and 91 kilograms of soybean meal (Glycine max; 46\% protein, Famo Feeds, Inc., Freeport, Minnesota, USA) over the course of the comparison which ended on June 16, 2020. Water losses due to evaporation required additional water to be added to all ponds during the study. Lake ponds received lake water as needed to keep ponds full, which is a typical practice at this hatchery. All well ponds received additional well water beginning on June 8 until they began overflowing.

\subsection{Zooplankton Sampling}

Zooplankton were sampled four times between May 19 and June 10, 2020. The initial sampling attempt occurred with a tow net, but filamentous green algae in lake water ponds reduced sampling efficiency (i.e., plugged the net). Instead, zooplankton were collected using a 3.2-liter, vertical Van Dorn sampler (Wildco, Yulee, Florida, USA) that was deployed to a depth of 0.95 meters beneath the surface at the drain structure of each pond. After collection, samples were immediately preserved in a $4 \%$ formalin solution that contained 40 grams sucrose per liter (Haney \& Hall, 1973). 
Table 1. Water chemistry description of Blue Dog Hatchery well and lake water during the spring

\begin{tabular}{lll}
\hline Parameter & Well & Lake $^{1}$ \\
\hline $\mathrm{pH}$ & 7.4 & 8.3 \\
Temperature $\left({ }^{\circ} \mathrm{C}\right)$ & 10.4 & 14.5 \\
Alkalinity $(\mathrm{mg} / \mathrm{L} \mathrm{CaCO})$ & 293 & 195 \\
Ammonia-N (mg/L) & 0.46 & 0.01 \\
Nitrate-N (mg/L) & $<0.2$ & 0.08 \\
Orthophosphate $(\mathrm{mg} / \mathrm{L})$ & $<0.02$ & $0.05^{*}$ \\
\hline
\end{tabular}

${ }^{1}$ Analysis completed by South Dakota Public Health Laboratory during June 2020

${ }^{2}$ Data taken from Steuven and Bren (1999)

*total phosphorus

Zooplankton (cladocera, copepod, and rotifer) enumeration for each sample was done by complete counts or subsampling. For complete counts, zooplankton density was determined as

$$
\text { Number of zooplankton / 3.2 Liters. }
$$

Subsampling occurred when samples visually contained higher numbers of zooplankton to expedite sample processing. Subsampling entailed uniformly distributing zooplankton and removing 1 milliliter aliquots (3X) using a pipette and placing in a counting wheel. All zooplankton for each taxon were enumerated through a dissecting microscope at 10 to $20 \mathrm{X}$ magnification for each aliquot and then averaged. When subsampling was employed, zooplankton density was determined as

(Average number of zooplankton per aliquot * dilution factor) / 3.2 Liters.

Zooplankton (cladocerans and copepods) were measured for length as described in the pooled data for each taxon in Bottrell et al. (1976). A maximum of 25 zooplankton were measured for each taxon per sample.

\subsection{Water Quality Sampling}

Dissolved oxygen (mg/L; Oakton PD 450 meter with RDO probe and sensor cap, Oakton Instruments, Vernon Hills, Illinois), $\mathrm{pH}$ (Oakton $\mathrm{pH} 150$ meter with electrode, Oakton Instruments, Vernon Hills, Illinois), and temperature ( ${ }^{\circ}$ Celsius; same equipment as dissolved oxygen) were measured twice each day on weekdays (except May 25) beginning at 9:00 a.m. and at 2:00 p.m. These measurements began on May 18 and continued through June 16, 2020. Due to the large number of samples for these variables ( $2 \mathrm{X}$ per day), we grouped these data into three timeframes; initial (May 18 to 27), middle (May 28 to June 6), and final (June 7 to 16). In each treatment, average values were determined among all measurements made within 
the indicated timeframe for both a.m. and p.m. periods. Measurements were made at the drain structure at a depth of 1.00 meter for dissolved oxygen and temperature, while $\mathrm{pH}$ was measured at a depth of 0.10 meters.

Ammonia-nitrogen (mg/L; salicylate method), nitrate-nitrogen $(\mathrm{mg} / \mathrm{L}$; cadmium reduction method), and orthophosphate (mg/L; ascorbic acid method) were measured from a 1-liter water sample collected from the drain structure at a depth of 0.15 meters in each pond. These measurements were made six times between May 19 and June 16, 2020 using a Hach DR2010 Spectrophotometer (Loveland, Colorado, USA). Total Alkalinity ( $\mathrm{mg} \mathrm{CaCO}_{3} / \mathrm{L}$; sulfuric acid titration to a $\mathrm{pH}$ of 4.8, Hach Kit, Loveland, Colorado, USA) was measured five times in each pond during this timeframe from the same 1-liter water sample used to determine nutrient concentrations. These measurements were not grouped into timeframes because they were not sampled as often as dissolved oxygen, $\mathrm{pH}$, and temperature.

\subsection{Chlorophyll-a and Phytoplankton Sampling}

Chlorophyll-a concentration $(\mu \mathrm{g} / \mathrm{L})$ was determined six times between May 20 and June 16, 2020. A minimum of 0.5 liters of pond water was filtered (filter specifications: 0.7 micron, $\mathrm{GF} / \mathrm{F}$ Whatman) and the volume filtered (milliliters) was recorded. The filters were frozen until being placed in 10 milliliters of acetone for chlorophyll-a extraction. A TD-700 fluorometer (Turner Designs, Sunnyvale, California, USA) was used to measure the fluorescence value $(\mu \mathrm{g} / \mathrm{L})$ of the acetone solute. Chlorophyll-a was calculated as

$$
\text { (Fluorescence value * acetone volume) / volume filtered. }
$$

Raw water samples (1-liter) were collected from only two ponds of each treatment on June 2 and 15, 2020, preserved (as instructed by EnviroScience biologists), and shipped to EnviroScience, Stow, Ohio, USA for phytoplankton identification by group (e.g., blue-green, cryptophyte, diatom, dinoflagellate, euglenoid, green, and yellow-green) and quantification (cells/mL).

\subsection{Statistics}

Means and standard errors were used to describe all water quality, chlorophyll-a, phytoplankton, and zooplankton data for each treatment. All comparisons were made with a sample size of 4 replicates per treatment except for the phytoplankton comparisons where sample size was 2. Statistical comparisons were made between treatments using a non-parametric Mann-Whitney $U$ test because the low sample sizes present difficulty in assessing if the data met assumptions of parametric statistics. Significance was set at 0.05.

\section{Results}

\subsection{Zooplankton}

Total zooplankton density was significantly lower in well ponds at all sampling dates (Mann-Whitney $U \geq 15.00, P \leq 0.04$; Figure 1a) and remained below 50 per liter throughout the comparison (Figure 1a). Cladoceran density was significantly lower in well ponds on May 19, 26, and June 2 (Mann-Whitney $\mathrm{U} \geq 15.00, P \leq 0.04$ ) but not on June 10 (Mann-Whitney 
$\mathrm{U}=14.00, P=0.08$; Figure 1b). Copepod density was significantly higher in lake ponds at every sampling date (Mann-Whitney $\mathrm{U}=16.00, P \leq 0.02$ ) and only reached 1 per liter in well ponds on June 10 (Figure 1c). Rotifer density remained low $(<5 / \mathrm{L})$ in both treatments throughout the comparison but was significantly higher in lake ponds on May 19 and 26 (Mann-Whitney $\mathrm{U} \geq 14.00, P \leq 0.05$ ).

Body size of cladoceran and copepod zooplankton was significantly larger on June 2 and 10 in lake ponds (Mann-Whitney $\mathrm{U}=16.00, P=0.02$; Table 2). No difference in zooplankton size was observed earlier in the comparison (Mann-Whitney $\mathrm{U} \leq 14.00, P \geq 0.08$ ).

Table 2. Mean $( \pm \mathrm{SE})$ length $(\mathrm{mm})$ of cladoceran and copepod zooplankton body size in lined ponds filled with either unfiltered well or lake water during 2020 at Blue Dog State Fish Hatchery, South Dakota, USA. Columns with differing superscripts indicate a significant difference $(P \leq 0.05)$. NS $=$ not sampled

\begin{tabular}{lllllllll}
\hline & May 18 & & May 26 & \multicolumn{3}{c}{ June 2 } & \multicolumn{3}{c}{ June 10 } \\
\cline { 2 - 8 } Treatment & Cladocera & Copepod & Cladocera & Copepod & Cladocera & Copepod & Cladocera & Copepod \\
\hline Lake & 1.32 & 0.43 & 0.94 & 0.68 & 1.13 & 1.30 & 1.54 & 1.07 \\
& $(0.09)$ & $(0.04)$ & $(0.10)$ & $(0.09)$ & $(0.03)^{\mathrm{y}}$ & $(0.18)^{\mathrm{y}}$ & $(0.08)^{\mathrm{y}}$ & $(0.07)^{\mathrm{y}}$ \\
\multirow{3}{*}{ Well } & NS & 0.12 & 0.79 & 0.36 & 0.81 & 0.49 & 1.25 & 0.30 \\
& & $(0.12)$ & $(0.10)$ & $(0.16)$ & $(0.01)^{\mathrm{z}}$ & $(0.18)^{\mathrm{z}}$ & $(0.03)^{\mathrm{z}}$ & $(0.18)^{\mathrm{z}}$ \\
\hline
\end{tabular}

\subsection{Water Quality}

Well ponds exhibited significantly lower $\mathrm{pH}$ during the initial (a.m. and p.m.) and final (only p.m.) periods (Mann-Whitney $U \geq 15.00, P<0.04$ ), but significantly higher $\mathrm{pH}$ during the middle period (only p.m.; Mann-Whitney $\mathrm{U}=0.00, P=0.02$; Table 3 ). Dissolved oxygen was significantly higher in well ponds throughout the entire culture interval (Mann-Whitney $\mathrm{U}=0.00, P=0.02$; Table 4). Water temperature tended to be significantly higher during the initial (a.m. and p.m.) and middle periods (only a.m.; Mann-Whitney $U \leq 1.00, P \leq 0.04$ ) but significantly lower during the final period in well ponds (a.m. and p.m.; Mann-Whitney $\mathrm{U}=16.00, P \leq 0.04$; Table 5). Mean temperature differences observed between treatments did not exceed $0.3{ }^{\circ}$ Celsius except for the p.m. comparison during the final period (Table 5).

Table 3. Mean ( \pm SE) pH for initial (May 18 to 27), middle (May 28 to June 6), and final (June 7 to 16) timeframes for both the morning (a.m.) and afternoon (p.m.) in 0.72-hectare lined ponds filled with either lake or well water during 2020. Differing superscripts indicate a significant difference $(P \leq 0.05)$

\begin{tabular}{lllllll}
\hline \multirow{2}{*}{ Treatment } & Initial & \multicolumn{3}{c}{ Middle } & Final \\
\cline { 2 - 7 } & a.m. & p.m. & a.m. & p.m. & a.m. & p.m. \\
\hline \multirow{2}{*}{ Lake } & 8.44 & 8.46 & 8.28 & 8.33 & 8.37 & 8.46 \\
& $(0.01)^{\mathrm{y}}$ & $(<0.01)^{\mathrm{y}}$ & $(0.01)$ & $(0.01)^{\mathrm{y}}$ & $(0.01)$ & $(0.01)^{\mathrm{y}}$ \\
\multirow{2}{*}{ Well } & 8.37 & 8.41 & 8.39 & 8.46 & 8.32 & 8.38 \\
& $(0.02)^{\mathrm{z}}$ & $(0.01)^{\mathrm{z}}$ & $(0.05)$ & $(0.04)^{\mathrm{z}}$ & $(0.02)$ & $(0.03)^{\mathrm{z}}$ \\
\hline
\end{tabular}



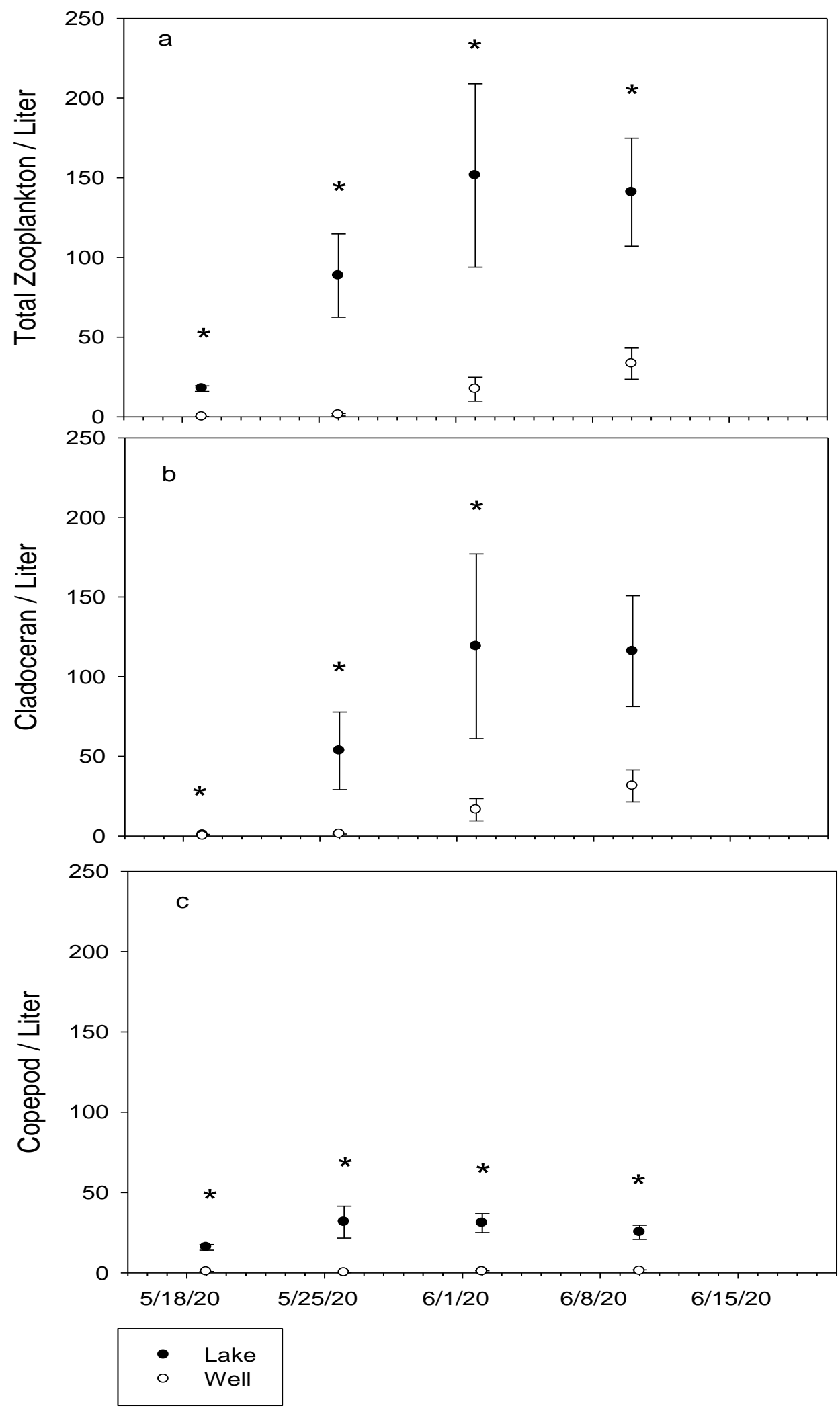

Figure 1. Mean ( \pm SE) total zooplankton (a), cladoceran (b), and copepod density (c) in 0.72 -hectare lined ponds filled with lake or well water. An asterisk indicates a significant difference $(P \leq 0.05)$ on that date 
Table 4. Mean $( \pm$ SE) dissolved oxygen concentration $(\mathrm{mg} / \mathrm{L})$ for initial (May 18 to 27), middle (May 28 to June 6), and final (June 7 to 16) timeframes for both the morning (a.m.) and afternoon (p.m.) in 0.72-hectare lined ponds filled with either lake or well water during 2020. Differing superscripts indicate a significant difference $(P \leq 0.05)$

\begin{tabular}{lllllll}
\hline & Initial & \multicolumn{3}{c}{ Middle } \\
\cline { 2 - 7 } Treatment & a.m. & p.m. & a.m. & p.m. & a.m. & p.m. \\
\hline Lake & $10.1(0.1)^{\mathrm{y}}$ & $10.9(0.3)^{\mathrm{y}}$ & $7.2(0.1)^{\mathrm{y}}$ & $8.2(0.1)^{\mathrm{y}}$ & $9.1(<0.1)^{\mathrm{y}}$ & $10.4(0.1)^{\mathrm{y}}$ \\
Well & $11.3(0.2)^{\mathrm{z}}$ & $13.0(0.3)^{\mathrm{z}}$ & $9.9(0.1)^{\mathrm{z}}$ & $11.5(0.3)^{\mathrm{z}}$ & $9.7(0.2)^{\mathrm{z}}$ & $11.0(0.2)^{\mathrm{z}}$ \\
\hline
\end{tabular}

Table 5. Mean ( \pm SE) water temperature $\left({ }^{\circ}\right.$ Celsius) for initial (May 18 to 27$)$, middle (May 28 to June 6), and final (June 7 to 16) timeframes for both the morning (a.m.) and afternoon (p.m.) in 0.72-hectare lined ponds filled with either lake or well water during 2020. Differing superscripts indicate a significant difference $(P \leq 0.05)$

\begin{tabular}{lllllll}
\hline \multirow{2}{*}{ Treatment } & Initial & \multicolumn{3}{c}{ Middle } & Final & \\
\cline { 2 - 7 } Lake & a.m. & p.m. & a.m. & p.m. & a.m. & p.m. \\
& 17.0 & 18.5 & 21.6 & 22.8 & 20.2 & 22.2 \\
\multirow{2}{*}{ Well } & $(0.1)^{\mathrm{y}}$ & $(<0.1)^{\mathrm{y}}$ & $(<0.1)^{\mathrm{y}}$ & $(0.1)$ & $(<0.1)^{\mathrm{y}}$ & $(<0.1)^{\mathrm{y}}$ \\
& 17.3 & 18.8 & 21.8 & 23.0 & 19.9 & 21.3 \\
& $(0.1)^{\mathrm{z}}$ & $(0.1)^{\mathrm{z}}$ & $(0.1)^{\mathrm{z}}$ & $(0.1)$ & $(0.2)^{\mathrm{z}}$ & $(0.1)^{\mathrm{z}}$ \\
\hline
\end{tabular}

Ammonia-nitrogen concentration began significantly higher in well ponds (Mann-Whitney $\mathrm{U}=0.00, P=0.02$ ), but tended to be significantly lower as the interval progressed (June 1-10, Mann-Whitney $\mathrm{U}=16.00, \quad P=0.02$; Figure 2a). The highest mean ammonia-nitrogen concentration for well ponds occurred on May 19 but not until June 8 for lake ponds. Nitrate-nitrogen concentration was less than $0.1 \mathrm{mg} / \mathrm{L}$ throughout the comparison and was never significantly different between treatments (Mann-Whitney $\mathrm{U} \geq 5.00, P \geq 0.31$; Figure 2b). Overall, both treatments exhibited a similar pattern in orthophosphate concentration with only one significant difference being detected on June 1 (Mann-Whitney $U=16.00, P=0.02$; Figure 2c). Alkalinity, however, was significantly different at four of the five comparisons (Figure 2d). In well ponds, alkalinity was higher on May 19 (Mann-Whitney $U=0.00, P=0.02$ ), but lower on June 1, 8, and 10 (Mann-Whitney $\mathrm{U}=16.00, P=0.02$ ). Alkalinity of lake ponds remained between 190 and $220 \mathrm{mg} / \mathrm{L}$ but varied from 150 to 280 in well ponds.

\subsection{Chlorophyll-a and Phytoplankton}

Chlorophyll-a concentration was significantly higher on May 26 (Mann-Whitney $U=0.00$, $P=0.02$ ) and significantly lower on June 16 (Mann-Whitney $\mathrm{U}=16.00, P=0.02$ ) in well ponds. Overall, a similar pattern in chlorophyll-a concentration was exhibited between treatments (Figure 2e).

Phytoplankton concentration was not significantly different for any alga group on either June 2 (Mann-Whitney $\mathrm{U} \leq 3.50, P \geq 0.10$ ) or 15 (Mann-Whitney $\mathrm{U} \leq 4.00, P \geq 0.12$ ). Greens, blue greens, cryptophytes, and diatoms were common on June 2 and 15 (Figure $3 \mathrm{a}$ and $b$ ). 

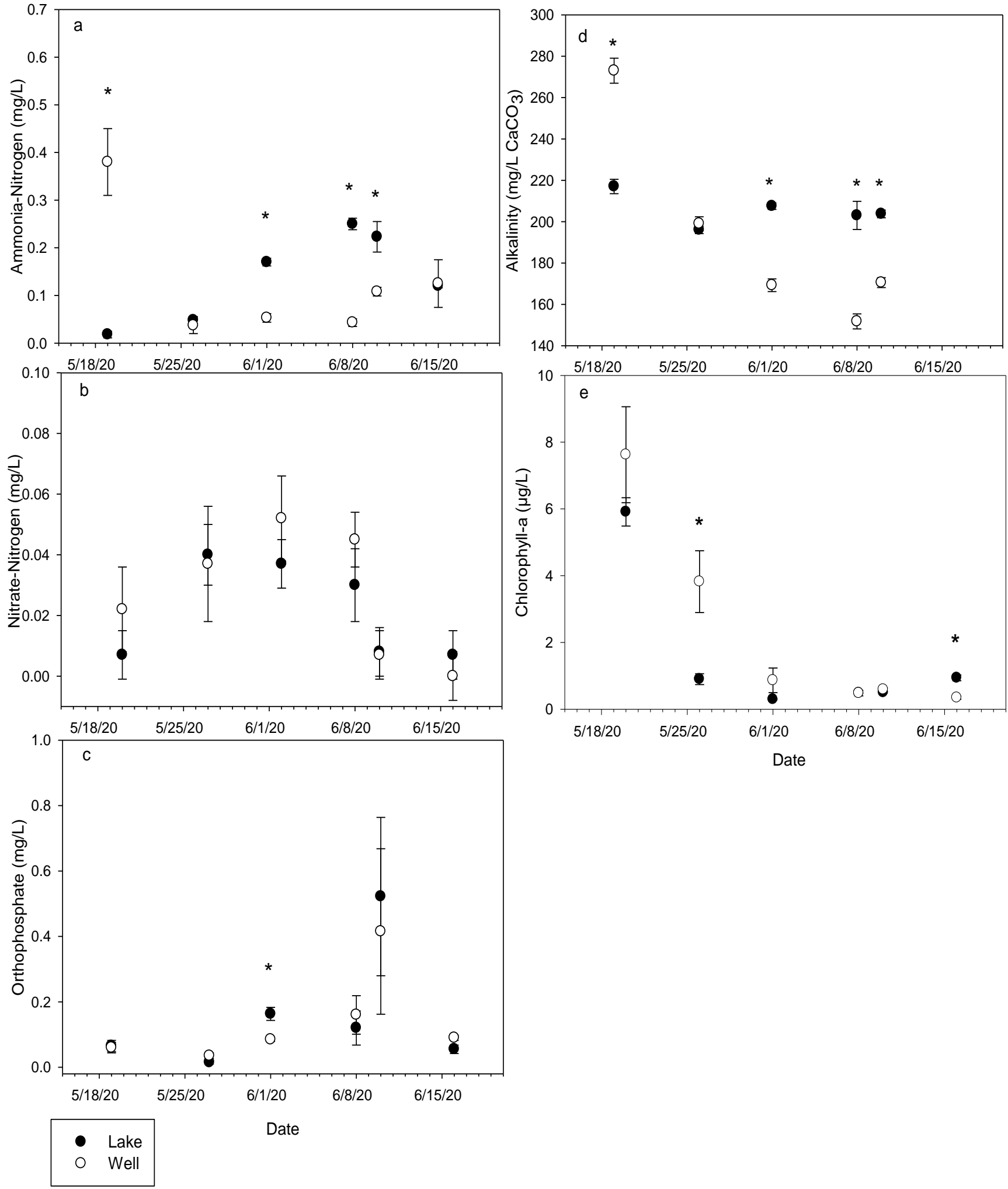

Figure 2. Mean $( \pm \mathrm{SE})$ ammonia-nitrogen (a), nitrate-nitrogen (b), orthophosphate (c), alkalinity (d), and chlorophyll-a (e) concentration at six dates in 0.72-hectare, lined ponds filled with lake or well water. An asterisk indicates a significant difference $(P \leq 0.05)$ on that date 

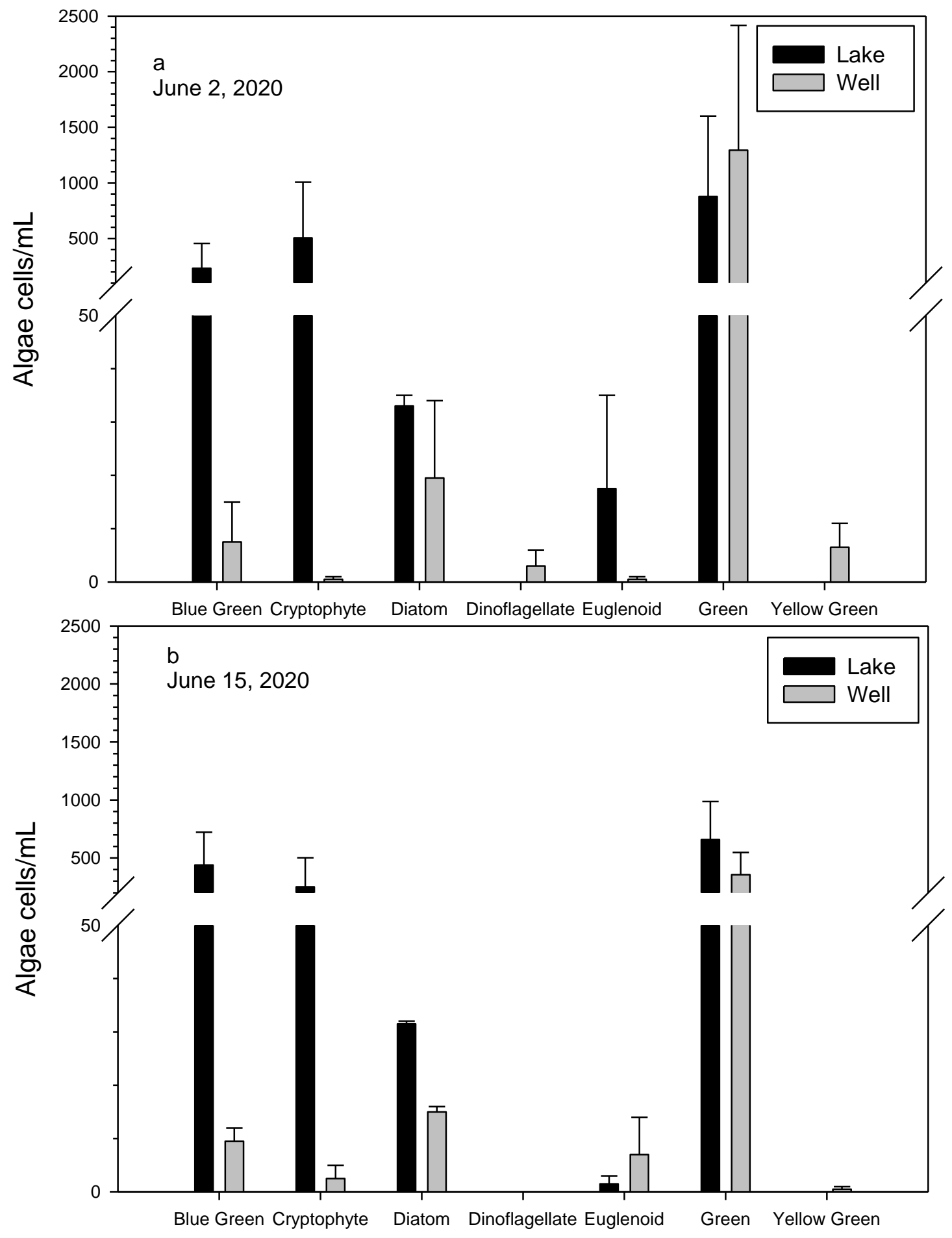

Figure 3. Mean concentration (cells/mL) for each alga group on June 2 (a) and 15 (b) in lined rearing ponds filled with either unfiltered lake or well water 


\section{Discussion}

Zooplankton density and body size were consistently lower in well ponds. Copepods were nearly undetectable in well ponds throughout the comparison and nauplii are important first prey of walleye (Summerfelt et al., 2011). Others report that walleye have an initial preference for larger copepods and cladocerans (Briland et al., 2015). In either scenario, the consistently lower density of zooplankton in well ponds suggest that walleye fry survival and growth to a harvestable size would be reduced because zooplankton remain important in walleye diets through at least the third week of pond culture (Summerfelt et al., 2011; Briland et al., 2015).

Well ponds exhibited higher ammonia-nitrogen and alkalinity as well as lower pH shortly after pond filling, which is expected based on the inherently different water chemistry of the two sources (Table 1). Following well water additions beginning on June 8, $\mathrm{pH}$ reverted to being lower and slight increases in ammonia-nitrogen and alkalinity occurred. Ground water typically exhibits differing chemistry than surface waters (Boyd \& Tucker, 2014) and the influence of well water chemistry in this study was apparent shortly after ponds were filled and water levels were maintained towards the end of the comparison.

Water temperature tended to be higher in well ponds through the initial and middle periods of the comparison, but then lower during the final period. Well ponds received water earlier than lake ponds and anecdotally, water levels remained higher in lake ponds. These two factors could explain the warmer temperatures during the initial and middle periods. Although significantly different, the largest temperature difference during this time was $0.3{ }^{\circ} \mathrm{Celsius}$ and thus contributed minimally to the biological processes occurring in the ponds. The largest difference $\left(0.9{ }^{\circ}\right.$ Celsius) occurred during the final period after well ponds had received additional water to compensate for evaporation losses. The lower temperature observed at this time could be attributed to well water being cooler than lake water during the month of June at this location.

Ammonia-nitrogen was lower between June 1 and 10, while $\mathrm{pH}$ was higher during the middle period in well ponds. Moreover, dissolved oxygen was consistently higher in well ponds throughout the comparison. Collectively, these measurements demonstrate that biological processes (e.g., photosynthesis or decomposition) varied between treatments. Higher levels of photosynthetic activity are typically accompanied by pronounced diurnal variation in $\mathrm{pH}$ (Boyd \& Tucker, 2014), which did not occur in either treatment. Decomposition of organic matter will release ammonia, consume dissolved oxygen, and decrease $\mathrm{pH}$ (Boyd \& Tucker, 2014). Hence, the higher dissolved oxygen and $\mathrm{pH}$, as well as lower ammonia-nitrogen are more likely a consequence of reduced decomposition of the organic fertilizer in well ponds.

Alkalinity was lower in well ponds at later dates, but did not decrease to levels (e.g., $50 \mathrm{mg} / \mathrm{L}$ ) that would reduce sportfish production (Boyd \& Tucker, 2014). Alkalinity values that exceed $200 \mathrm{mg} / \mathrm{L}$ can reduce phytoplankton productivity due to decreasing phosphorus solubility (Boyd \& Tucker, 2014). The initial alkalinity for well and nearly all measurements for lake ponds exceeded $200 \mathrm{mg} / \mathrm{L}$. Orthophosphate concentrations in both treatments, however, exceeded recommendations in other fertilization regimens (Culver, 1996; Jacob \& Culver, 
2010), which suggests that soluble reactive phosphorus would not be limiting. Regardless of water source, the consistently low nitrate-nitrogen concentrations $(<0.1 \mathrm{mg} / \mathrm{L})$ indicate that most of the ammonia is getting used by phytoplankton before being converted to nitrate (Boyd \&Tucker, 2014).

Chlorophyll-a concentration was not statistically different between treatments on May 20 and was higher on May 26 in well ponds. Phytoplankton blooms are generally slower to develop in ponds filled with ground water (Summerfelt et al., 2011), so the results of the current study were partially contrary. The initially higher ammonia-nitrogen concentration and lower zooplankton density may have promoted phytoplankton development (Culver, 1996; Qin \& Culver, 1996) and the increased chlorophyll-a concentration on May 26 in well ponds. The lower zooplankton density in well ponds, however, did not allow for phytoplankton or chlorophyll-a concentrations to increase relative to lake ponds after May 31. This suggests that the organic fertilizer was used more efficiently to support higher zooplankton density in lake ponds. A phytoplankton bloom was successfully initiated in well ponds, but maintaining the bloom was difficult despite lower zooplankton density.

\section{Summary and Recommendations}

Lined ponds filled with unfiltered water from either lake or well sources and fertilized with organics exhibited differences in zooplankton, water quality, and chlorophyll-a. Reduced zooplankton abundance throughout the comparison suggests that walleye fry survival and growth would not be favorable in ponds filled with well water. Water quality was influenced by the inherent difference in chemistry between well and lake sources as well as biological processes, presumably slower decomposition of the organic fertilizer in well ponds. Chlorophyll-a data demonstrated that a bloom was successfully initiated but was difficult to maintain even with a lower zooplankton density in well ponds. While the use of well water would enhance biosecurity, the results of this study indicate that walleye fingerling production would be reduced relative to lined ponds filled with productive, lake water. Future efforts to fill ponds earlier (e.g., 30 days), increase organic fertilizer and/or supplement with liquid 28N:0P:0K may provide a more favorable environment for walleye culture in lined ponds filled with well water.

\section{Acknowledgment}

We thank J. Broughton and R. Smidt for their assistance with the collection, review, and publication of this data. Thanks to Dr. S. Chipps for his assistance with determining chlorophyll-a concentrations.

\section{References}

Barkoh, A., \& Rabeni, C. F. (1990). Biodegradability and nutritional value to zooplankton of selected fertilizers. The Progressive Fish-Culturist, 52, 19-25. https://doi.org/10.1577/1548-8640(1990)052<0019:BANVTZ>2.3.CO;2

Bottrell, H. H., Duncan, A., Gliwicz, Z. M., Grygierek, E., Herzig, A., Hillbricht-Ilkowska, A., ... Weglenska, T. (1976). A review of some problems in zooplankton production studies. 
Norwegian Journal of Zoology, 24, 419-456.

Boyd, C. E. (1990). Water Quality in Ponds for Aquaculture. Alabama Agricultural Experiment Station, Auburn University, Auburn.

Boyd, C. E., \& Tucker, C. S. (2014). Handbook for Aquaculture Water Quality, Craftmasters Printers, Inc., Auburn, Alabama.

Briland, R. D., Doyle, C. M., \& Culver, D. A. (2015). Large-scale production of yellow perch, walleye, and hybrid walleye in ponds. In P. Kestemont, K. Dabrowski, \& R.C. Summerfelt (Eds.), Biology and Culture of Percid Fishes, 469-498, Springer, New York. https://doi.org/10.1007/978-94-017-7227-3_18

Chakraborti, R. K., Madon, S., \& Kaur, J. (2016). Costs for controlling dreissenid mussels affecting drinking water infrastructure: case studies. Journal - American Water Works Association, 108, E442-E453. https://doi.org/10.5942/jawwa.2016.108.0104

Culver, D. A., Madon, S. P., \& Qin, J. (1993) Percid Pond Production Techniques: Timing, enrichment, and stocking density manipulation. Journal of Applied Aquaculture, 2, 9-31. https://doi.org/10.1300/J028v02n03_02

Culver, D. A. (1996). Fertilization procedures for pond culture of walleye and saugeye. In R.C. Summerfelt (Ed.), Walleye Culture Manual, 115-122. North Central Regional Aquaculture Center Publications Office, Iowa State University, Ames.

Harding, L. M., \& Summerfelt, R. C. (1993). Effects of fertilization and of fry stocking density on pond production of fingerling walleye. Stizostedion vitreum. Journal of Applied Aquaculture, 2, 59-79. https://doi.org/10.1300/J028v02n03_04

Haney, J. F., \& Hall, D. J. (1973). Sugar coated Daphnia: A preservation technique for Cladocera. Limnology and Oceanography, 18, 331-333. https://doi.org/10.4319/lo.1973.18.2.0331

Jacob, A. P., \& Culver, D. A. (2010). Experimental manipulation of the impacts of reduced inorganic phosphorus fertilization rates on juvenile saugeye production. Aquaculture, 304, 22-33. https://doi.org/10.1016/j.aquaculture.2010.03.019

Karatayev, A. Y., Lyubov, E., \& Burlakova, D. K. (2015). Zebra versus quagga mussels: a review of their spread, population dynamics, and ecosystem impacts. Hydrobiologia, 746, 97-112. https://doi.org/10.1007/s10750-014-1901-x

Qin, J., \& Culver, D. A. (1992). The survival and growth of larval walleye, Stizostedion vitreum, and trophic dynamics in fertilized ponds. Aquaculture, 108, 257-276. https://doi.org/10.1016/0044-8486(92)90111-W

Qin, J., \& Culver, D. A. (1995). Effect of young-of-the-year walleye (Percidae: Stizostedion vitreum) on plankton dynamics and water quality in ponds. Hydrobiologia, 297, 217-227. https://doi.org/10.1007/BF00019286

Qin, J., \& Culver, D. A. (1996) Effect of larval fish and nutrient enrichment on plankton 
dynamics in experimental ponds. Hydrobiologia, 321, 109-118. https://doi.org/10.1007/BF00023168

Rogge, M. L., Moore, A. A., \& Morris, J. E. (2003). Organic and mixed organic-inorganic fertilization of plastic-lined ponds for fingerling walleye culture. North American Journal of Aquaculture, 65, 179-190. https://doi.org/10.1577/C02-022

Smith, L. L., \& Moyle, J. B. (1945). Factors influencing production of yellow pike-perch, Stizostedion vitreum vitreum, in Minnesota rearing ponds. Transactions of the American $\begin{array}{llll}\text { Fisheries } & \text { Society, } & \text { 243-261. }\end{array}$ https://doi.org/10.1577/1548-8659(1943)73[243:FIPOYP]2.0.CO;2

Soderberg, R. W. (2012). Organic and inorganic fertilization. In C.C. Mischke (Ed.), Aquaculture Pond Fertilization: Impacts of Nutrient Input on Production. John Wiley \& Sons, Inc, Blackwell Publishing, Ames, Iowa. https://doi.org/10.1002/9781118329443.ch3

Stueven, E. H., \& Bren, R. (1999). Phase 1 watershed assessment final report, Blue Dog Lake, Day County, South Dakota. South Dakota Department of Environment and Natural Resources, Pierre.

Summerfelt, R. C., Clouse, C. P., \& Luzier, J. M. (1996). Walleye fingerling culture in drainable ponds. In R.C. Summerfelt (Ed.), Walleye Culture Manual, 89-108. North Central Regional Aquaculture Center Publications Office, Iowa State University, Ames.

Summerfelt, R. C., Johnson, J. A., \& Clouse, C. P. (2011). Culture of walleye, sauger, and hybrid walleye. In B.A. Barton (Ed.), Biology, Management, and Culture of Walleye and Sauger, 451-570. American Fisheries Society, Bethesda, Maryland. https://doi.org/10.47886/9781934874226.ch13

\section{Copyrights}

Copyright for this article is retained by the author(s), with first publication rights granted to the journal.

This is an open-access article distributed under the terms and conditions of the Creative Commons Attribution license (http://creativecommons.org/licenses/by/4.0/) 